\title{
Flow tests of an air controlling throttle body in a spark ignition engine
}

\author{
The paper presents a flow testing method for throttle bodies. The numerically obtained values of the flow capacity was \\ used for the development of their characteristics that can be implemented in the simulation models.
}

Key words: combustion engine, fuel delivery system, throttle body, investigations

\section{Badanie przepływowe zespołu przepustnicy sterującego napelnieniem silnika spalinowego o zapłonie iskrowym}

\begin{abstract}
$W$ artykule przedstawiono metodę przepływowych badań zespołów przepustnic. Wyznaczone $w$ toku identyfikacji numerycznej wartości przepustowości postużyty do opracowania ich charakterystyk, które można zaimplementować do modeli symulacyjnych.
\end{abstract}

Słowa kluczowe: silnik spalinowy, układ zasilania, zespót przepustnicy, badania

\section{Introduction}

Most of the modern spark ignition engines are characterized by a similarity in terms of the air intake system. The components of the air intake system are already optimized at the design stage assuming a variety of criteria, the main being the obtaining of the required cylinder filling coefficient under operating conditions. Further optimization of the system takes place on the test stands. The geometrical characteristics (variability) of the individual intake system components influences the engine torque. The basis for the operation of the spark ignition engine is the control of the charge amount in the cylinder (classic approach) i.e quantitative control. The element that directly participates in this process is the throttle body. It has been fitted in both old carburetor and modern cutting edge technology engines based on fuel injection with the exception of the Valvetronic system where the throttle choking has been eliminated in favor of valve choking (realized through a variable valve lift).

The throttle controls the air flowing into the cylinders and its position decides about the external engine indexes and their adequacy to the current conditions assuming that other systems such as fuel delivery and ignition are fully operative. With time the technical condition of systems deteriorates and the influence of the system shortcomings gets stronger. The improper operation of the system is mostly caused by contamination, excessive wear or simply damage of individual parts of the system. The same works for the throttle body, hence the need to clean it regularly and then calibrate it.

\section{The object of the research}

The object of the research were three of throttle bodies different in terms of design. Having tested the variants shown in Fig. 1, the authors concluded that it is purposeful to apply two channel throttles (Fig. 1b) or a particular shape on the air intake side (Fig. 1c) against the classic solution (Fig. 1a).

\section{Wstęp}

Większość współcześnie budowanych silników o ZI cechuje podobieństwo pod kątem układu zasilania powietrzem. Elementy układu dolotowego optymalizuje się już w fazie projektu, przyjmując różnorodne kryteria, z których głównym jest osiągnięcie odpowiedniego współczynnika napełnienia cylindra w bieżących warunkach pracy. Dalsza optymalizacja odbywa się w toku badań na stanowiskach badawczych. Od charakterystyki geometrycznej (jej zmienności) poszczególnych elementów zależy wartość momentu obrotowego generowanego przez silnik. Podstawą działania silnika o ZI jest sterowanie ilością ładunku w cylindrze (w ujęciu klasycznym), czyli sterowanie ilościowe. Elementem, który bezpośrednio bierze w tym udział jest przepustnica. Znalazła ona zastosowanie zarówno w gaźnikowych układach zasilania, jak i w najnowocześniejszych układach wtryskowych, poza układem Valvetronic, gdzie dławienie przepustnicy zastąpiono dławieniem układu rozrządu realizowanym przez zmienny skok zaworu.

Przepustnica reguluje przepływ powietrza napływającego do cylindrów i od jej położenia zależą wskaźniki zewnętrze silnika, ich adekwatność do bieżących warunków, przy założeniu, iż układy zasilania paliwem, zapłonowy i inne, działają poprawnie. $Z$ czasem stan techniczny pogarsza się, nasila się wpływ niedomagań powodujących zakłócenia w działaniu poszczególnych elementów. Niedomagania te powstają przede wszystkim w wyniku zanieczyszczeń, nadmiernego zużycia, uszkodzeń poszczególnych części. Dotyczy to również przepustnicy, stąd też należy ją okresowo oczyszczać i dodatkowo adoptować.

\section{Przedmiot badań}

Przedmiotem badań były trzy różniące się konstrukcyjnie zespoły przepustnic. Poddając badaniu przedstawione na rys. 1 warianty, wnioskowano o celowości stosowania przepustnic dwuprzelotowych (rys. 1b), czy odpowiednich ukształtowań w części wlotowej (rys. 1c) względem klasycznego rozwiązania (rys. 1a). 
a)

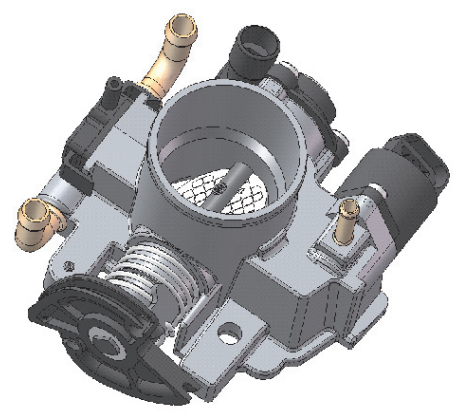

b)

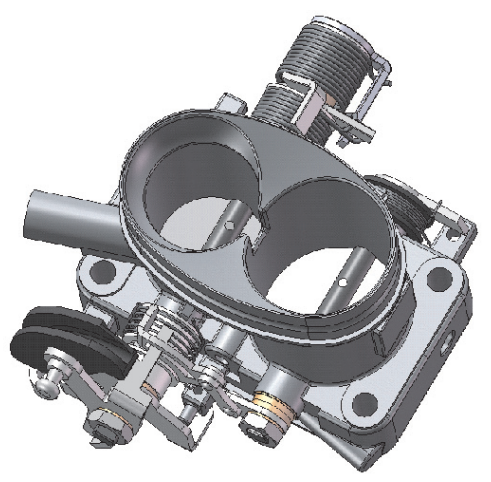

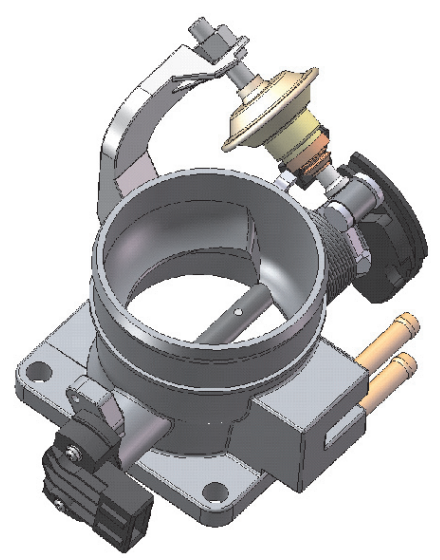

Fig. 1. Throttle bodies under investigation: a) classic, b) two stage, c) having a profiled air intake Rys. 1. Badane zespoly przepustnic: a) klasyczna, b) dwustopniowa, c) z profilowanym wlotem

The throttle body presented in Fig. 1a was designed for a Polonez motor vehicle of capacity $1.6 \mathrm{dm}^{3}$, GSI operating with a multipoint electronic gasoline injection. It was selected for the tests because its build is typical of the majority of MPI systems and constitutes a reference for the tests of less typical solutions. The system has a single channel with a single throttle. The main part chokes the air depending on given engine operating condition, in the bypass circuit we have the idle adjustment valve and the fuel vapor supply from the fuel tank. Both the bypass circuit and the fuel vapor supply were shut for the testing because in other throttle bodies these systems were not fitted.

The throttle body shown in Fig. 1b comes from a VW Golf II of capacity $2 \mathrm{dm}^{3}$, MPI operating with a multipoint hydraulic fuel injection ${ }^{1)}$. This represents a group of two channel throttles, where the first stage channel of smaller active diameter chokes the air in low and medium engine speeds and the second stage of higher active diameter- medium and approximating maximum engine speeds.

Figure 1c shows a throttle fitted in a $2.8 \mathrm{dm}^{3}$, VR6 by VW. Similarly to the throttle in Fig. 1a it has a single channel but it has a profiled air intake.

\section{Research methodology}

In the investigations aiming at the determining of the flow capacity of the throttle a dynamic method was used consisting in the determining of the courses of pressure changes in the measurement tank, where in the path of he flow induced by a pressure difference between the tank and the surroundings a distortion is generated in the form of throttle opening (Fig. 2a). This method was successfully applied in the investigations of pneumatic subassemblies of brake systems (Miatluk 1980; Miatluk, Kamiński, Czaban 2003) as well as in the investigations of engine air intake systems, (Rawski 1980).

\footnotetext{
1) Multipoint fuel injection systems KE-Jetronic or KE-Motronic are commonly mistaken for mechanical fuel injection systems even though the fuel dosage system uses hydraulic differential valves.
}

Zespół przepustnicy przedstawiony na rys. 1a pochodzi z silnika samochodu Polonez o objętości skokowej 1,6 dm³, GSI i współpracuje z wielopunktowym elektronicznym układem wtryskowym benzyny. Został wybrany do celów badawczych dlatego, że ma budowę typową dla większości układów MPI i stanowi odniesienie do badań mniej typowych rozwiązań. Posiada jeden przelot z pojedynczą przepustnicą. W części zasadniczej mamy do czynienia z dławieniem przepływu powietrza w zależności od bieżącego stanu działania silnika, w obwodzie obejściowym - z zaworem regulacji biegu jałowego, jak też układem doprowadzania oparów paliwa ze zbiornika. Zarówno obwód obejściowy, jak i układ doprowadzania oparów paliwa ze zbiornika zostały na czas pomiarów zamknięte, ponieważ w pozostałych przepustnicach układy te nie występowały.

Zespół przepustnicy przedstawiony na rys. 1b wymontowano z silnika samochodu VW Golf II o objętości skokowej $2 \mathrm{dm}^{3}$, MPI współpracującym z wielopunktowym hydraulicznym układem wtryskowym benzyny ${ }^{1)}$. Reprezentuje ona grupę przepustnic dwuprzelotowych, gdzie przelot pierwszego stopnia o mniejszej powierzchni czynnej dławi przepływ powietrza w zakresie małych i średnich zapotrzebowań, natomiast drugi o większej powierzchni - w zakresie średnich i dążących do maksymalnych.

Na rysunku 1c pokazana jest przepustnica znajdująca zastosowanie w silniku o objętości skokowej $2.8 \mathrm{dm}^{3}$, VR6 firmy VW. Podobnie jak przepustnica na rys. 1a posiada ona pojedynczy przelot, natomiast cechą, która ją wyróżnia jest profilowany wlot.

\section{Metodyka badań}

W badaniach do wyznaczenia przepustowości zespołu przepustnicy wykorzystano metodę dynamiczną, polegającą na wyznaczaniu przebiegów czasowych zmian ciśnienia

\footnotetext{
1) Wielopunktowe układy wtrysku benzyny KE-Jetronic lub KE-Motronic bardzo często mylnie nazywane są mechanicznymi układami wtryskowymi, choć w układzie dawkowania paliwa wykorzystuje się hydrauliczne zawory różnicowe.
} 
The measurements began from a full throttle opening and were continued until its full closure. The opening was successively reduced with no adjustment on the side of the components controlling the air flow in the bypass channel.

For the tests a test stand shown in Fig. $2 b$ was used. During the tests a vacuum of approximately $20 \mathrm{kPa}$ was generated in the tank. Such a value has been determined in the works of Wendeker (1999) and the author of this paper (2005) as a pressure occurring in the intake system when the engine accelerates.

Unfortunately due to significant differences in the way the air flowed the operating conditions of the throttle are different from those in the real engine. The flow in the measuring stand is indeed variable as it is in the case of a real engine but the real flow in the engine is of pulsatory nature. Because of that, at the same air expenditure, the pressures in both cases are different. That is why the course of the obtained characteristics is dependent on the build of the test stand.

Based on the recorded measurement results we can state that there is a mass air flow through a local drag (Fig. 2a). However, because the flow process is characterized by a high complexity of the occurring phenomena, simplifications have been introduced as follows:

- the air is treated as an ideal gas of a constant specific heat

- the flow takes place without internal friction and heat exchange with the surroundings

- the state of the air is constant in a given diameter and depends on time

- the tested portion is treated as a pipe of a constant diameter

- the joints of the individual elements of the tested object are perfectly airtight.

Having considered the above assumptions, the stream of air flowing through the local drag can be expressed:

$$
\dot{\mathrm{m}}=(\mu \mathrm{A}) \cdot \frac{\mathrm{p}_{\mathrm{a}}}{\mathrm{R} \cdot \mathrm{T}} \cdot \mathrm{v}_{\max } \cdot \varphi_{\max }(\sigma) \cdot \varphi(\sigma)
$$

and the change of mass $\mathrm{dm} / \mathrm{dt}$ of air in the measurement tank of volume $\mathrm{V}_{\mathrm{z}}$ can be expressed:

$$
\frac{\mathrm{dm}}{\mathrm{dt}}=\frac{\mathrm{V}_{\mathrm{z}}}{\kappa \cdot \mathrm{R} \cdot \mathrm{T}} \cdot \frac{\mathrm{dp}_{\mathrm{z}}}{\mathrm{dt}}
$$

where: $\mathrm{p}_{\mathrm{a}}$ - atmospheric pressure $[\mathrm{Pa}], \mathrm{p}_{\mathrm{z}}$ - pressure in the measurement tank $[\mathrm{Pa}], \mathrm{V}_{\mathrm{z}}$ - volume of the measurement tank $\left[\mathrm{m}^{3}\right], \mu$ - flow coefficient, $\mathrm{A}-$ area of free flow $\left[\mathrm{m}^{2}\right], \mathrm{T}-$ air temperature before the drag $[\mathrm{K}], \mathrm{R}$ - gas constant for air $\mathrm{R}=287,9[\mathrm{~J} /(\mathrm{kg} \cdot \mathrm{K})], \mathrm{v}_{\mathrm{m}}-$ speed of sound propagation in a stationary gas $\mathrm{v}_{\mathrm{m}}=\sqrt{\kappa \cdot \mathrm{R} \cdot \mathrm{T}}, \kappa-$ adiabate exponent $\kappa=1.405, \varphi_{\max }(\sigma)-\mathrm{St}^{\prime}$ Venant and Wantzel function maximum value, $\varphi_{\max }=\sqrt{(2 /(\mathrm{k}+1))^{\frac{\mathrm{K}+1}{k-1}}}=0.578, \varphi(\sigma)$ - dimensionless function of flow, the form according to Miatluk-Avtuszko, adjusted by the author (Szpica 2005), $\varphi(\sigma)=1.07 \cdot(1-\sigma) /(1,07-\sigma)$.

The final model of the adiabatic process of the filling of the measurement tank we can express in the form of a differential equation: w zbiorniku pomiarowym, gdzie na drodze przepływu wywołanego różnicą ciśnień zbiornik-otoczenie zadaje się zakłócenie w postaci stopnia uchylenia przepustnicy (rys. 2a). Metodę tę $\mathrm{z}$ powodzeniem stosowano powszechnie $\mathrm{w}$ badaniach podzespołów pneumatycznych układów hamulcowych (Miatluk 1980; Miatluk, Kamiński, Czaban 2003), jak również w badaniach układów dolotowych silników spalinowych (Rawski 1980).

a)

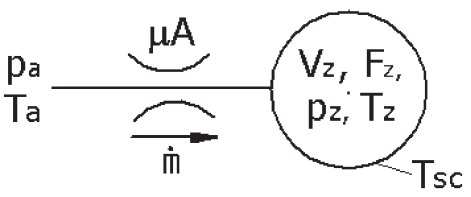

b)

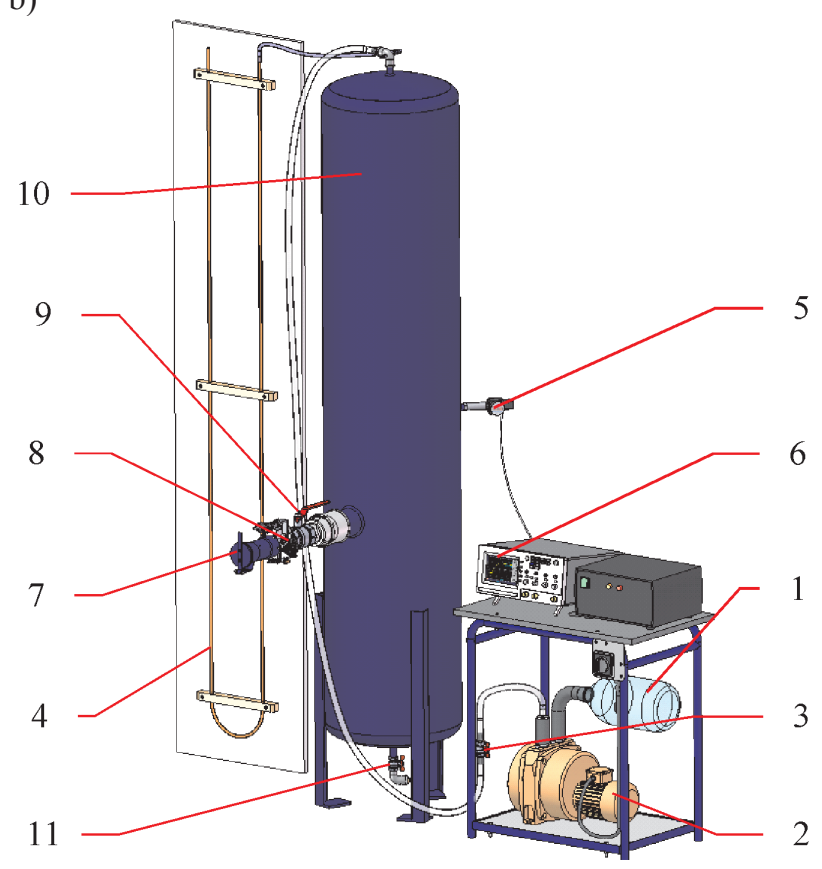

Fig. 2. Test stand: a) schematics, b) 3D view: 1 - displacement tank, 2 - vacuum pump, 3, 9 - limiting ball valve, 4 - pipe manometer, 5 - ZPWM pressure sensor , 6 - oscilloscope GDS-2102, 7 - flap diffuser, 8 - tested object, 10 - measurement tank, 11 - draining valve

Rys. 2. Stanowisko pomiarowe: a) schemat ideowy, b) widok 3D: 1-zbiornik wypustowy, 2-pompa próżniowa, 3, 9-kulowy zawór ograniczajacy, 4-manometr rurkowy, 5-czujnik ciśnienia ZPWM, 6-oscyloskop GDS-2102, 7 -dyfuzor z klapka, 8-badany obiekt, 10 - zbiornik pomiarowy, 11 - zawór odwadniajacy

Pomiary rozpoczęto od pełnego otwarcia przepustnicy i prowadzono je aż do jej całkowitego zamknięcia. Sukcesywnie zmniejszano otwarcie, nie zmieniając położenia organów regulujących przepływ powietrza w kanale obejściowym.

Do celów badawczych wykorzystano stanowisko pomiarowe widoczne na rys. 2 b. Na potrzeby pomiarów w zbiorniku pomiarowym wytwarzano podciśnienie rzędu $20 \mathrm{kPa}$. Wartość ta została określona w opracowaniach Wendekera (1999) i autora (2005) jako ciśnienie występujące w układzie dolotowym w czasie przyspieszania pojazdu.

Niestety, ze względu na dość znaczne różnice w sposobie przepływu powietrza warunki pracy przepustnicy 


$$
\frac{\mathrm{dp}_{\mathrm{z}}}{\mathrm{dt}}=\frac{\kappa \cdot \mathrm{R} \cdot \mathrm{T}}{\mathrm{V}_{\mathrm{z}}} \cdot\left((\mu \mathrm{A}) \cdot \frac{\mathrm{p}_{\mathrm{a}}}{\mathrm{R} \cdot \mathrm{T}} \cdot \mathrm{v}_{\max } \cdot \varphi_{\max }(\sigma) \cdot \varphi(\sigma)\right)
$$

Based on the experimentally recorded courses of pressure changes in the filled tank the model pressure courses were determined. The values of flow capacity were determined using the non-linear regression, minimizing the function described by FPE1 by the Nelder-Mead method, until the required accuracy of calculation was reached:

$$
\mathrm{FPE} 1=\frac{\mathrm{m}+1}{\mathrm{~m}(\mathrm{~m}-1)} \sum_{\mathrm{i}=1}^{\mathrm{m}}\left(\mathrm{p}_{\mathrm{lz}}-\mathrm{p}_{\mathrm{m}}\right)^{2}
$$

where: $\mathrm{m}$ - number of points of the identified curve, $1-$ number of significant model coefficients.

An additional criterion of evaluation of the matching level of the pressure courses was the coefficient of non-linear regression adjusted to the degrees of freedom:

$$
\mathrm{R}^{2}=1-\frac{\mathrm{m}-1}{\mathrm{~m}-1} \cdot \frac{\sum_{\mathrm{i}=1}^{\mathrm{m}}\left(\mathrm{p}_{1 \mathrm{z}}-\mathrm{p}_{\mathrm{m}}\right)^{2}}{\sum_{\mathrm{i}=1}^{\mathrm{m}}\left(\mathrm{p}_{\mathrm{iz}}-\overline{\mathrm{p}_{\mathrm{m}}}\right)^{2}}
$$

The creation of reference pressure course changes of the filled tank and obtaining the results in the form of flow parameters is possible through solving the differential equation (3). For this purpose Matlab software was used, where a logical algorithm was created numerically solving the equation by the method of Runge-Kutty.

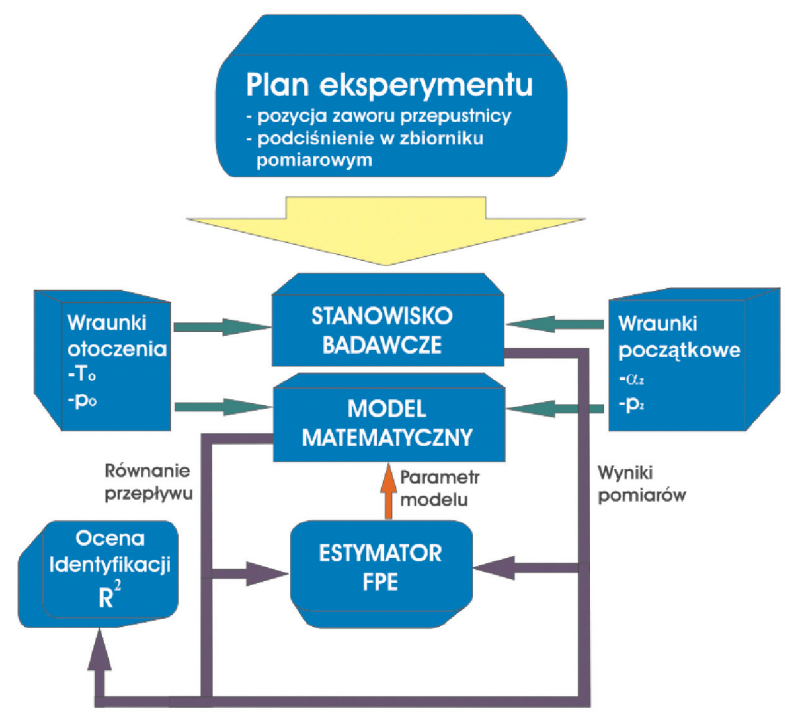

Fig. 3. Schematics of the process of identification Rys. 3. Schemat procesu identyfikacji

To obtain a clear and ordered system of communication in the process of identification (Fig. 3) an interface shown in Fig. 4 has been developed.

\section{Test results and analysis}

The process of numerical identification comprised the determining of the value of flow capacity $\mu \mathrm{A}$ as a product na stanowisku różnią się od warunków pracy na silniku. Wprawdzie przepływ na stanowisku jest nieustalony, tak jak ma to miejsce w silniku, jednak rzeczywisty przepływ w silniku ma dodatkowo charakter pulsacyjny. W związku $\mathrm{z}$ tym przy jednakowym wydatku powietrza, panujące $\mathrm{w}$ obydwu przypadkach podciśnienia różnią się od siebie. Dlatego przebieg otrzymanej charakterystyki jest zależny od konstrukcji stanowiska.

Na podstawie zarejestrowanych wyników pomiarów można wnioskować o masowym przepływie powietrza przez opór miejscowy (rys. 2a). Jednakże z uwagi na to, iż proces przepływu charakteryzuje się dużą złożonością zjawisk, wprowadzono założenia upraszczające; najważniejsze to:

- powietrze traktowane jest jako gaz doskonały o stałym cieple właściwym

- przepływ odbywa się bez tarcia wewnętrznego i wymiany ciepła z otoczeniem

- stan powietrza jest niezmienny w danym przekroju i zależy od czasu

- badany odcinek traktowany jest jako rura o stałym przekroju

- połączenia poszczególnych elementów badanego obiektu są doskonale szczelne.

Po uwzględnieniu powyższych założeń, strumień masy powietrza przepływającego przez opór miejscowy można zapisać wzorem (1).

Z kolei zmianę masy dm/dt powietrza w zbiorniku pomiarowym o objętości $\mathrm{V}_{\mathrm{z}}$ wzorem (2), gdzie: $\mathrm{p}_{\mathrm{a}}$ - ciśnienie atmosferyczne $[\mathrm{Pa}], \mathrm{p}_{\mathrm{z}}-$ ciśnienie $\mathrm{w}$ zbiorniku pomiarowym [Pa], $\mathrm{V}_{\mathrm{z}}$ - objętość zbiornika pomiarowego $\left[\mathrm{m}^{3}\right], \mu$ - współczynnik przepływu, A - pole swobodnego przepływu $\left[\mathrm{m}^{2}\right], \mathrm{T}-$ temperatura powietrza przed oporem $[\mathrm{K}], \mathrm{R}-$ stała gazowa, dla powietrza $\mathrm{R}=287,9[\mathrm{~J} /(\mathrm{kg} \cdot \mathrm{K})]$, $\mathrm{V}_{\mathrm{m}}$ - prędkość rozchodzenia się dźwięku w nieruchomym gazie $\mathrm{v}_{\mathrm{m}}=\sqrt{\kappa \cdot \mathrm{R} \cdot \mathrm{T}}, \kappa-$ wykładnik adiabaty $\kappa=1,405, \varphi_{\max }(\sigma)$ - wartość maksymalna funkcji St'Venanta i Wantzela, $\varphi_{\max }=\sqrt{(2 /(\kappa+1))^{\kappa-1}}=0,578, \varphi(\sigma)$-bezwymiarowa funkcja przepływu, postać wg Miatluka-Avtuszko, skorygowana przez autora (Szpica 2005), $\varphi(\sigma)=1,07 \cdot(1-\sigma) /(1,07-\sigma)$.

Ostateczny model adiabatycznego procesu napełniania powietrzem stałej objętości zbiornika pomiarowego można przedstawić w postaci równania różniczkowego (3).

Na podstawie zarejestrowanych doświadczalnie przebiegów zmian ciśnienia w napełnianym zbiorniku wyznaczono przebiegi modelowe. Wartości przepustowości $\mu \mathrm{A}$ wyznaczano, wykorzystując regresję nieliniową, minimalizując metodą Neldera-Meada funkcję celu określoną wskaźnikiem FPE1, aż do osiągnięcia żądanej dokładności obliczeń - wzór (4), gdzie: m - liczba punktów identyfikowanej krzywej, 1 - liczba istotnych współczynników modelu.

Dodatkowym kryterium oceny stopnia dopasowania przebiegów ciśnień był współczynnik regresji nieliniowej skorygowany na stopnie swobody (5).

Stworzenie wzorcowych przebiegów zmian ciśnienia napełnianego zbiornika oraz uzyskanie wyników w postaci parametrów przepływu możliwe jest przez rozwiązanie 
of the flow coefficient and the current area of free flow. Assuming a constant value of the flow coefficient the characteristics shown in Fig. 5 reflect the variability of the area of free flow. Unfortunately the assumption of flow coefficient constancy in the whole range of throttle flap opening is a major simplification. In the author's work (2005) the test results of the throttle in different variants of the model test stands have been scrutinized. The first was a test identical to that presented herein, the second took place on a different test stand, where the throttle was fitted together with the intake system and a cylinder block. Knowing the flow capacities of

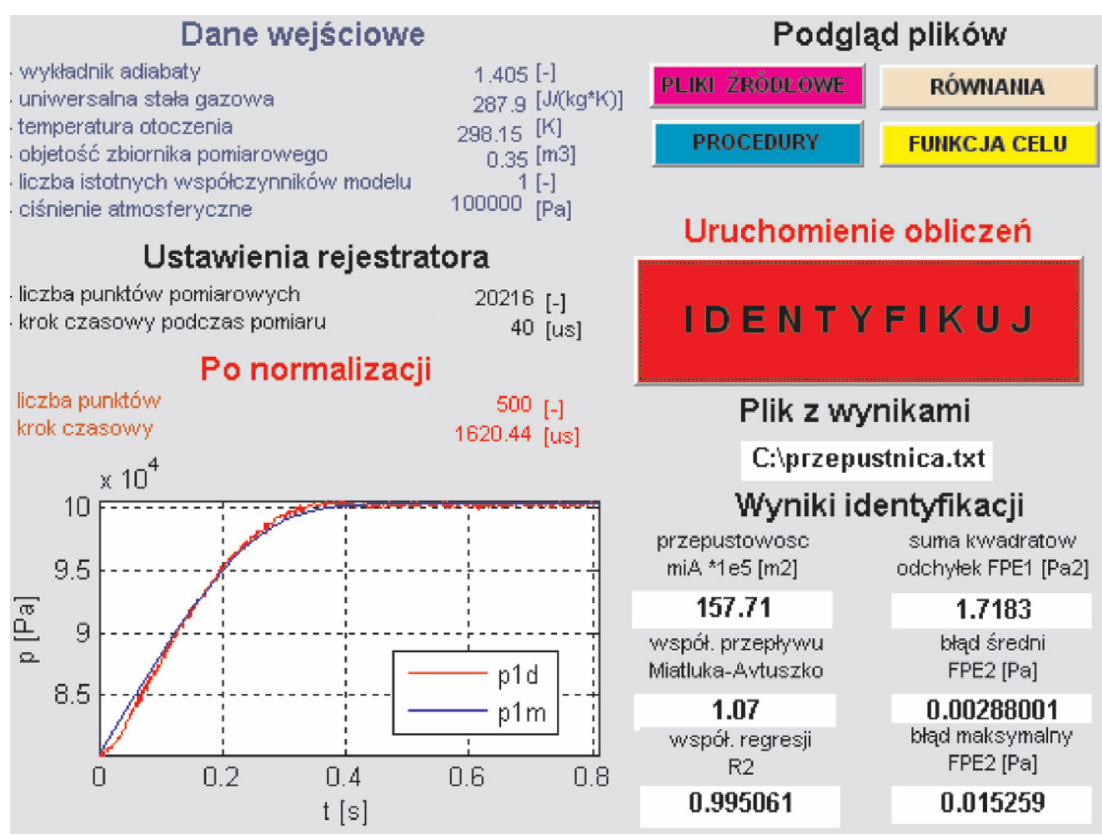

Fig. 4. Software panel for the identification of flow parameters created in the Matlab-Simulink environment, add-on GUIDE

Rys. 4. Panel programu do identyfikacji parametrów przeplywu stworzony $w$ środowisku Matlab-Simulink, dodatek GUIDE

the intake system and the intake duct including the variable valve opening, flow capacity was determined while the valve timing system operated.

The test results in the complete configuration of the system and the throttle alone did not differ above $5 \%$. This confirmed the correctness of the assumed investigation method, which is currently used in the investigations related to pneumatics.

The selection of the measurement tank may be a problem here, which serves as a mass air flow meter; its size was chosen as per the guidelines set forth by Rawski (1980).

Despite the difference in the design of the throttle subassemblies in the main part i.e. the part responsible for the size of the air stream delivered to the engine their characteristics are similar. Subtle differences are in the initial part at small openings where the throttle with a profiled intake provides a minimum flow at openings up to 20o. Here, the bypass system that was fitted outside the throttle is responsible for the air flow. Above 40o the profiled throttle has a higher flow capacity than the other ones due to larger równania różniczkowego (3). Do tego celu wykorzystano program Matlab, w którym stworzono algorytm obliczeniowy, numerycznie rozwiązujący to równanie metodą Rungego-Kutty.

W celu uzyskania uporządkowanego i przejrzystego systemu komunikacji w procesie identyfikacji (rys. 3) stworzono interfejs graficzny widoczny na rys. 4.

\section{Wyniki badań i ich analiza}

Proces identyfikacji numerycznej obejmował wyznaczenie wartości przepustowości $\mu \mathrm{A}$ jako iloczynu współczynnika przepływu i aktualnej powierzchni swobodnej przepływu. Przy założeniu stałej wartości współczynnika przepływu charakterystyki przedstawione na rys. 5 odzwierciedlają zmienność swobodnego pola przepływu. Niestety, przyjęcia stałości współczynnika przepływu w całym zakresie uchyleń listka przepustnicy jest sporym uproszczeniem. W pracy autora (2005) poddano szczegółowej analizie wyniki badań przepustnicy w różnych wariantach stanowisk modelowych. Pierwsze obejmowało badanie identyczne do przedstawionego $\mathrm{w}$ tym miejscu, drugie natomiast na odrębnym stanowisku, gdzie przepustnicę zamontowano wraz z układem dolotowym i blokiem cylindrów. Znając przepustowości układu dolotowego i kanału dolotowego wraz ze zmienną szczeliną zaworową, poszukiwano przepustowości przepustnicy przy pracującym układzie rozrządu.

Wyniki badań w konfiguracji kompletnej układu i indywidualnej samej przepustnicy nie różniły się maksymalnie pow. 5\%. Pozwala to wnioskować o poprawności przyjętej metody badań, która obecnie jest wykorzystywana w pneumatyce.

Pewnym problemem w tym miejscu jest dobór objętości zbiornika pomiarowego, który pełni rolę przepływomierza; jego wielkość została dobrana wg wytycznych przedstawionych przez Rawskiego (1980).

Pomimo różnic w konstrukcji podzespołów przepustnic w części głównej, tj. odpowiedzialnej za wielkość strumienia masy powietrza dostarczanego do silnika, ich charakterystyki są zbliżone. Subtelne różnice kryją się w części początkowej, przy małych otwarciach, gdzie przepustnica z profilowanym wlotem zapewnia minimalny przepływ przy otwarciach do $20^{\circ}$. W tym miejscu za przepływ powietrza odpowiada układ obejściowy, który zamontowano w tym układzie poza przepustnicą. Powyżej $40^{\circ}$ przepustnica profilowana przewyższa przepustowością pozostałe z uwagi na swoją średnicę przelotu. Pomimo iż przepustnica dwuprzelotowa sumarycznie charakteryzuje się większą średnicą przelotu, to zakłócenie przepływu wywołane rozgałęzieniem strugi i powierzchnią dwóch listków daje gorszy efekt, niż przypadek przepustnicy profilowanej. Biorąc pod uwagę wynikowe 
diameter of its channels. Even though the two channels of the throttle when summed up give a larger diameter, the flow distortion triggered by the branching of the stream and the area of the two flaps gives a worse effect as compared to the profiled throttle. Taking the result characteristics into account, a classic throttle can be seen as a compromise. In the initial phase, up to 30 o of the opening, it is similar to the two channel throttle but in the final phase it is more like the profiled throttle. Hence, most of the engine manufacturers use classic throttle in their solutions with mechatronic systems based on feedback, phasing out the original Bowden cable control. Apart form that, the principle of operation and the tasks are still the same.

While evaluating the process of identification in terms of quality we can notice that the sum of the squares of the deviations was on a medium level of approximately $0.6 \cdot 10^{-5} \mathrm{~m}^{4}$ and average value $\mathrm{R}_{\text {sr }}^{2}=0.995$ (Fig. 6, 7).

\section{Conclusions}

The presented method of investigations and the characteristics of the throttles allow an update of the simulation models by equations where the variability of the area of free flow diameter and the variability of the flow coefficient are included. The data available in literature related to the description of the variability of the flow area are complex and frequently need a modification to adapt for current

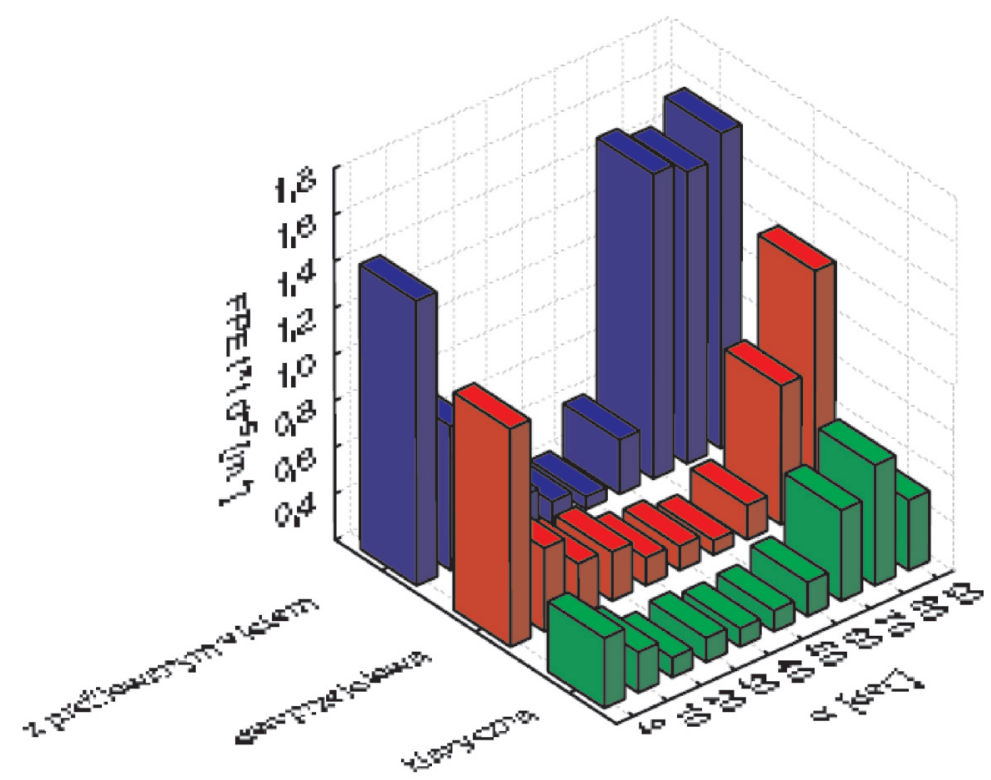

Fig. 6. FPE1 values obtained through numerical identification

Rys. 6. Wartości wskaźnika FPE1 uzyskane w toku identyfikacji numerycznej charakterystyki, przepustnicę klasyczną można uznać za pewnego rodzaju kompromis. W początkowej fazie, do $30^{\circ}$ otwarcia, jest zbliżona do przepustnicy dwuprzelotowej, natomiast w końcowej części do przepustnicy profilowanej. Stąd też większość firm produkujących silniki wykorzystuje w swoich rozwiązaniach przepustnice klasyczne, choć ostatnio zamiast linki sterującej otwarciem znajdziemy w nich układy mechatroniczne ze sprzężeniem zwrotnym. Pomimo tego istota działania i zadania przepustnicy pozostały niezmienne.

Oceniając jakościowo proces identyfikacji, można zauważyć, iż suma kwadratów odchyłek mieściła się w zakresie średnim ok. $0,6 \cdot 10^{-5} \mathrm{~m}^{4}, \mathrm{z}$ kolei wartość średnia $\mathrm{R}_{\text {sr }}^{2}=0,995$ (rys. 6, 7).

\section{Podsumowanie}

Przedstawiona metoda badań oraz zaprezentowane charakterystyki zespołów przepustnic pozwalają na uzupełnienie modeli symulacyjnych o równania, w których uwzględniono równocześnie zmienność pola swobodnego przekroju przepływu i zmienność współczynnika przepływu. Dostępne w literaturze zależności na opis zmienności pola przepływu są rozbudowane i często wymagają ich modyfikacji względem bieżącego otwarcia. Nie można również przy tym uwzględnić stałości współczynnika przepływu w całym zakresie otwarcia.

Ocena właściwości przepływowych, w przypadku badań opisanych w artykule, ma charakter ilościowy i nie poddaje analizie jakość przepływu, tj. trajektorie ruchu strugi, prędkości, przyspieszenia, czy różnice temperatur. Zagadnienie to zostanie poddane analizie w następnych publikacjach zwią- 
opening. We cannot include the constancy of the flow coefficient in the whole range of opening.

The assessment of the flow properties in the case of the investigations described in the paper has a quantitative nature and does not analyze the quality of the flow i.e. the trajectory of the stream motion, speed acceleration or the differences in temperature. This issue will be analyzed in further publications related to the air flow through the throttle body. Preliminary simulation tests have already been performed with the use of the Cosmos Flow (Solid Works) software that provided additional information, as to the influence of the differences in design on the flow process.

The characteristics of the throttles presented in the paper were approximated with

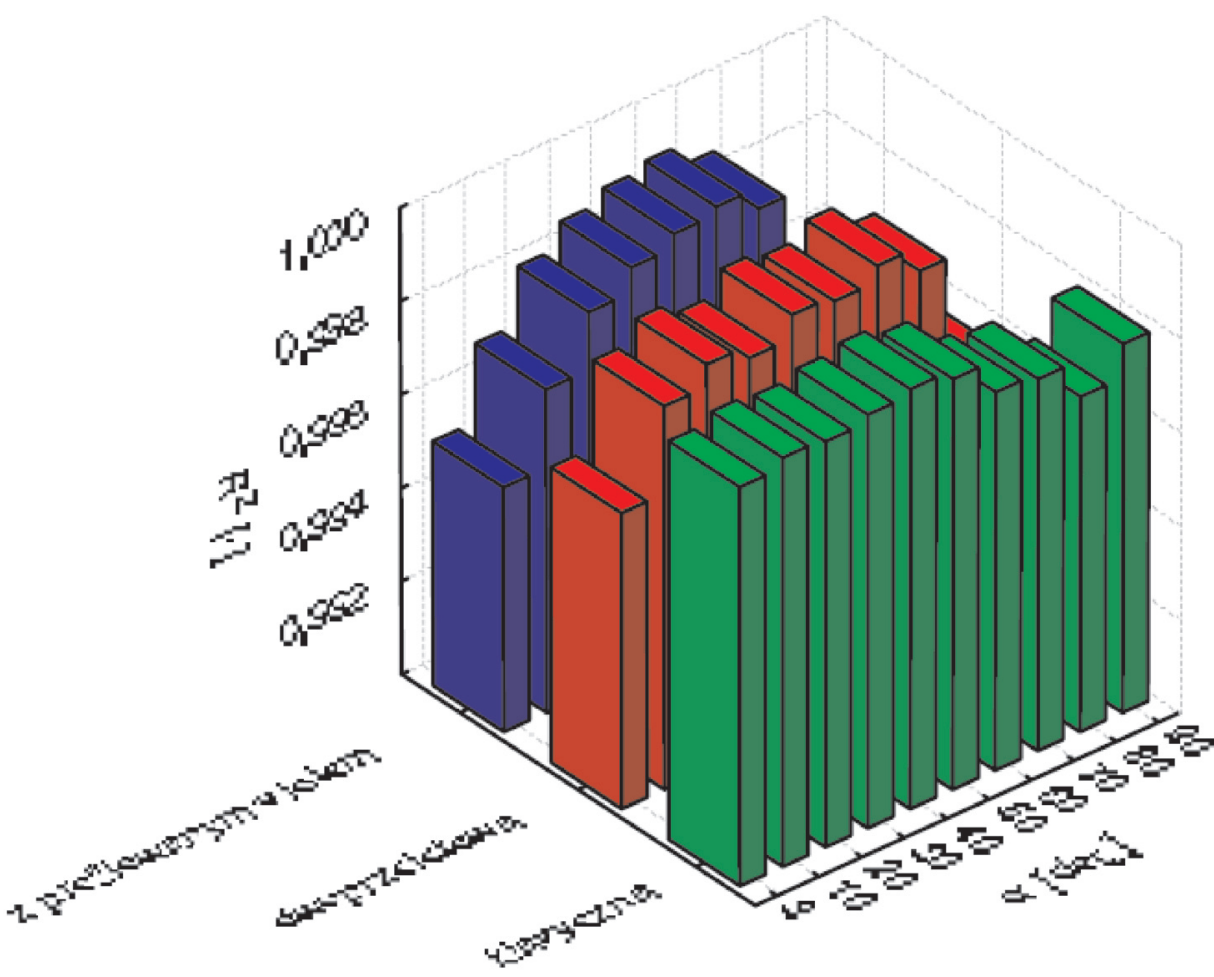

Fig. 7. Values of the non-linear regression coefficient R2 obtained through numerical identification Rys. 7. Wartości współczynnika regresji nieliniowej R2 uzyskane w toku identyfikacji numerycznej a $4^{\text {th }}$ order multinomial, which should also be construed as a certain simplification even though in some cases this may complicate the mathematical model of the engine. That is why a qualitative analysis of various functions adjusting the characteristics of the throttle (based on Gauss) has been performed of a lower number of coefficients which will be presented in further papers.

Artykut recenzowany zanych z przepływem powietrza przez zespół przepustnicy. Przeprowadzono już wstępne badania symulacyjne $\mathrm{z}$ wykorzystaniem oprogramowania Cosmos Flow (pakiet Solid Works), które dostarczyły dodatkowych informacji odnośnie do wpływu różnic konstrukcyjnych na proces przepływu.

Charakterystyki przepustnic przedstawione $\mathrm{w}$ artykule aproksymowano wielomianem 4. stopnia, co też należy uznać za pewnego rodzaju uproszczenie, choć w pewnym stopniu, w niektórych przypadkach może to komplikować model matematyczny silnika. Dlatego przeprowadzono analizę jakościową różnych funkcji dopasowujących charakterystykę przepustnicy (np. na bazie Gaussa), o mniejszej ilości współczynników, co zostanie zaprezentowane w kolejnych opracowaniach.

\section{Bibliography/Literatura}

[1] Miatluk M.F., Avtuszko W.P.: Dynamika pnievmatičeskich i gidravličeskich privodov avtomobliej, Izdatielstwo Maszinostrojenije, Moskva 1980.

[2] Miatluk M., Kamiński Z., Czaban J.: Characteristic features of the airflow of pneumatic elements of agricultural vehicles,

Mr. Dariusz Szpica, DEng. - doctor in the Faculty of Mechanical Engineering at Bialystok University of Technology.

Dr inż. Dariusz Szpica - adiunkt na Wydziale Mechanicznym Politechniki Biatostockiej.

e-mail: dszpica@pb.bialystok.pl
Commission of Motorization and Power Industry in Agriculture, vol. 3, 2003.

[3] Puławski G., Szpica D.: Eksperymentalne i symulacyjne badania przepustnicy silnika o ZI (ref.), XXVII Seminarium Kół Naukowych "Mechaników", Warszawa 24-25.04.2008.

[4] Rawski F.: Proces napełniania cylindra przez układ dolotowy silnika tłokowego jako obiekt regulacji, Silniki Spalinowe, Wyd. Zakładów Przemysłu Metalowego H. Cegielskiego w Poznaniu, nr 2, Poznań 1980.

[5] Szpica D.: Badanie procesu zasilania powietrzem cylindrów silnika spalinowego, rozprawa doktorska, Politechnika Białostocka 2005.

[6] Wendeker M.: Sterowanie napełnieniem w silniku samochodowym, Lublin 1999. 